Pamiętnik Literacki 2017, 4, s. 5-13
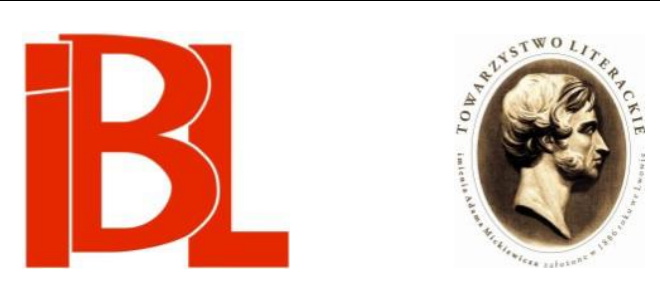

\title{
Kurpiowskie Eleusis. O bohaterkach „Brzeziny” Jarosława Iwaszkiewicza
}

\author{
Marcin Całbecki
}




\section{1. $\begin{array}{lllllllllllllllllll} & \mathrm{R} & \mathrm{O} & \mathrm{Z} & \mathrm{P} & \mathrm{R} & \mathrm{A} & \mathrm{W} & \mathrm{Y} & \mathrm{I} & \mathrm{A} & \mathrm{R} & \mathrm{T} & \mathrm{Y} & \mathrm{K} & \mathrm{U} & £ & \mathrm{Y}\end{array}$}

Pamiętnik Literacki CVIII, 2017, z. 4, PL ISSN 0031-0514

DOI: $10.18318 / \mathrm{pl} .2017 .4 .1$

MARCIN CAŁBECKI Uniwersytet Gdański

\section{KURPIOWSKIE ELEUSIS O BOHATERKACH „BRZEZINY” JAROSŁAWA IWASZKIEWICZA}

\section{Kto jest bohaterem Brzeziny?}

Wydaje się, że temat mitycznego tła Brzeziny Jarosława Iwaszkiewicza został już szczegółowo i wyczerpująco omówiony. Oczywiście najważniejszym studium poświęconym temu zagadnieniu jest Eros $i$ Tanatos Ryszarda Przybylskiego, gdzie para tytułowych greckich bogów patronuje perypetiom skonfliktowanych bohaterów, którzy - w zależności od położenia - poddają się władaniu raz jednego, raz drugiego bóstwa. W opinii Przybylskiego Brzezina opisuje w zasadzie wyłącznie los schorowanego i umierającego Stasia, choć badacz zastrzega, że ważną rolę odgrywa tu również Bolesław:

Brzezina jest przede wszystkim opowieścią o umierającym Stasiu. Ale jednocześnie jest to opowiadanie o żyjącym, choć zarażonym śmiercią Bolesławie, którego z pesymistycznego odrętwienia, ze stanu zatrucia i półbytu wytrąca właśnie umieranie i śmierć brata ${ }^{1}$.

Według Przybylskiego w centrum omawianego utworu sytuują się dwaj bohaterowie męscy, uwiedzeni i powodowani przez parę bóstw męskich, będących - podobnie jak Bolesław i Stanisław - braćmi. W opowiadaniu występuje wprawdzie jeszcze Malwina, ale ta nie zajmuje w takim stopniu uwagi badacza i reprezentuje, jego zdaniem, typowy dla prozy Iwaszkiewicza model kobiecości utożsamianej z „siłą życia” $i$ „mityczną prazasadą bytu”. Jest nazywana także „bahofenicznym symbolem trwania, ponieważ posłuszna prawom natury pilnuje przede wszystkim miłości, która gwarantuje prokreacje życia"2.

Gdyby pójść tropem Przybylskiego, który los Stanisława kontrastuje doświadczeniami Bolesława, to również w przypadku Malwiny można odnaleźć antynomiczny odpowiednik wśród żeńskich postaci opowiadania i stwierdzić, że tej sile życia sprzeciwiają się absolutne śmierć i nicość, będące zaprzeczeniami witalności - truchłem. Nie tylko umierający Staś ma swe alter ego, ma je także Malwina. Jest nim bowiem pochowana nieopodal leśniczówki żona Bolesława - Barbara. O niej jednak

1 R. Przybylski, Eros i Tanatos. Proza Jarosława Iwaszkiewicza 1916-1938. Warszawa 1970, S. 182 .

2 Ibidem, s. 188. 
od Przybylskiego nie dowiadujemy się zbyt wiele. Barbara, a dokładniej - jej śmierć, stanowi przyczynę rozterek Bolesława: „Zmarła Basia kieruje jego myślami i postępowaniem" ${ }^{3}$. Jeśli jednak o losie bohaterów decyduja w równym stopniu Eros i Tanatos, to wydaje się, że trzeba by zaakcentować funkcję, jaką w opowiadaniu pełni Barbara - jej postać w całości przynależy do domeny tanatycznej, tak jak pod znakiem Erosa upływa życie Malwiny. Można bowiem odnieść wrażenie, że tajemnica Brzeziny, tajemnica życia i śmierci rozgrywa się w czworokącie Stanisław-Bolesław-Malwina-Barbara, skupianie zaś uwagi wyłącznie na męskich bohaterach istotnie zubaża wieloaspektowość dzieła. Podobnie wskazanie tylko na braterski patronat Erosa i Tanatosa łączy się z pominięciem jeszcze jednej mitycznej inicjacji umożliwiającej oswojenie się z myślą o śmierci i towarzyszącej jej nadziei pokładanej w miłości. Tym misterium jest kult Demeter w Eleusis i związany z nim obrzęd ku czci bogini Kory, żony Hadesa, która - poświęcona śmierci - była wszak córką bogini płodności.

\section{Barbara i brzezina}

$Z$ jakich powodów staram się przesunąc nieco akcenty postawione przez Przybylskiego i dowartościować postaci kobiece, które - w moim przekonaniu - są równoprawnymi bohaterkami opowiadania i tylko traktowanie ich w taki sam sposób, jak mężczyzn pozwala w całej okazałości odsłonić mityczne podglebie opowiadania? Otóż pierwszym sygnałem wskazującym na niebagatelną rolę kobiet jest funkcja tytulatury. Co bowiem symbolizuje tytułowa „brzezina”? Jest to, jak wiadomo, miejsce pochówku Barbary, ale i miejsce schadzek Stanisława i Malwiny. Widać zatem, że także ów topos nacechowany jest wyraźnym rozchwianiem semantycznym, ewidentną dychotomią, którą daje się zauważyć, kiedy analizuje się wiele wątków opowiadania. Warto odwołać się do samego tekstu, aby rozpoznać, jakim metamorfozom uległ ów osobliwy cmentarz i jak postrzegany jest ten istotny, bo tytułowy motyw. Wszak we wnętrzu „zarażonego śmiercią” Bolesława - w chwili, kiedy spogląda on na mogiłę Barbary - dokonuje się znacząca przemiana.

Gdy wyszedł za stajnię, za sosny, jak gdyby po raz pierwszy także zobaczył brzezinę, gdzie leżała żona. [...] Pnie te, białe, gładkie, toczone, przypominały mu tutaj ramiona kobiece, mnóstwo splątanych ramion, wznoszacych sie w górę gestami błagania, uniesienia, czasem odgiętych ku dołowi ruchem poddania i rezygnacji. [...] Wilgotne, parne powietrze napełniało zgęszczeniem interwały pomiędzy brzozami i wszystko razem czyniło wrażenie jakiejś zmysłowej świątyni. [I 369] ${ }^{4}$

Przybylski wskazuje na podobna, choć przebiegająca w przeciwnych kierunkach metamorfozę Stasia i Bolesława. Staś związany ze sferą Erosa przechodzi w dramatycznych okolicznościach na stronę śmierci. Odwrotnie Bolesław, ten odkrywa miłość i - jak czytamy w końcowych fragmentach opowiadania - pełen nadziei wraca do życia. Warto jednak podkreślić, że przemiany nie ograniczają się wyłącznie do postaci męskich. W przypadku opisu brzeziny także dokonuje się znamienne przesu-

3 Ibidem, s. 183.

4 Skrótem I odsyłam do: J. I w a szk i e w i c z, Brzezina. W: Brzezina i inne opowiadania ekranizowane. Wstęp A. W e rn er. Warszawa 1987. Liczby po skrócie oznaczają stronice. 
nięcie znaczeń. Oto cmentarz przeobraża się w zmysłową świątynię, a drzewa górujące nad mogiłą Barbary zaczynaja przypominać ciało kobiece. Należałoby więc zapytać, czy w związku z tym w wizji Bolesława nie ożywa również jego żona, której truchło właśnie w brzezinie spoczywa. Czy zatem ów opis nie ukazuje metamorfozy Barbary, która dzięki sile natury przypomina o sobie i swej zmysłowości? Przyroda wszak to w tym opowiadaniu domena kobieca, w zasadzie można by rzec, że natura jest tu samą kobiecością. Barbara więc to nie tylko wielka nieobecna, lecz także ktoś, kto w utworze Iwaszkiewicza ujawnia się poprzez imaginację Bolesława i współtworzy harmonię erotyczną, opisaną przez Przybylskiego.

Brzezina, której korzenie wrosły w trumnę Barbary, staje się zatem zmysłowa kobieta - tak ją widzi Bolesław. W wielu fragmentach opowiadania zaobserwować można proces utożsamiania kobiety i brzozy:

Zdjął ręce z brzozy i dotknął tej osoby, która stała przy nim; uczuł te same szorstkości i gładkość, co na brzozowej korze, te same krople rosy, ten sam chłód. [I 363]

Wprawdzie cytat ten odnosi się do Stanisława, który spotyka Malwinę, jednak myśli gruźlika zaprząta w tym czasie zmarła Barbara, na co wskazywał passus poprzedzający opis schadzki. Zatem Stanisław spotyka tyleż zmysłową Malwinę, co zmarłą Barbarę, jednak obecność owych kobiet uwydatnia się za pomocą epifanii natury, epifanii drzewa. Poprzez symbol brzozy dokonuje się wyraźne utożsamienie Malwiny i Barbary, obie niejako są obecne w dotyku Stanisława. To zacieranie się tożsamości bohaterek opowiadania, analogiczne do paralelnych przemian Bolesława i Stanisława, wskazywać może na mityczne tło wydarzeń opisanych w Brzezinie. Także misteria eleuzyńskie wiązały się z czczeniem dwóch bogiń, które traktowane były zawsze jako nierozerwalna jedność. Tak przynajmniej twierdzi Karl Kerényi. Wspomina on, że „W Eleusis bóstwo misteryjne [...] znane było publiczności jako "boska dwójnia", w formie dualis mogącej znaczyć zarówno "dwaj

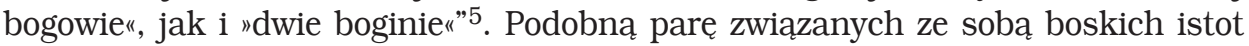
opisuje też Roberto Calasso:

Kora i Demeter sa jedną istotą podwójną i nawet noszą to samo imię (Deo). Każdemu czynowi jednej odpowiada, czasami w olśniewającej transpozycji, czyn drugiej ${ }^{6}$.

Z podobnym związkiem dwu postaci kobiecych, z których jedna zamieszkuje już królestwo cieni, druga zaś staje się symbolem życia, obfitości i płodności, mamy do czynienia w opowiadaniu Iwaszkiewicza. Wprawdzie nie są to matka i córka, lecz więź Malwiny i Barbary, właśnie poprzez wzajemne uzupełnianie się w imaginacji Stanisława, wydaje się niepodważalna. Obie stanowią symbol zagadki życia i śmierci, obie są wobec siebie komplementarne, obie też stają się obsesją dwóch braci i w zasadzie pełnią równie ważne funkcje w utworze Iwaszkiewicza, co Stanisław i Bolesław.

Do pary dwóch postaci kobiecych dołącza się zaś symbol roślinny - ściślej dendrologiczny - to tytułowa brzezina. Towarzysząca zaś tym przeobrażeniom fi-

5 K. Ke ré ny i, Eleusis. Archetypowy obraz matki i córki. Przeł. I. Ka ni a. Kraków 2004, s. 61.

$6 \quad$ R. Cala s s o, Zaślubiny Kadmosa z Harmonia. Przeł. S. Ka s przy s i a k. Wprowadzenie J. B r o ds ki. Kraków 1995, s. 314. 
gura drzewa każe doszukiwać się wątków związanych $\mathrm{z}$ uobecnieniem się w opowiadaniu także mitów mówiących o cykliczności i rytmie wegetacji, więc odwołujących się do misteriów eleuzyńskich. Zatem nie tylko Eros i Tanatos, lecz też Demeter i Kora patronują owej historii. Domniemanie to może się wydać pewną nieścisłością, gdyż porwanie Persefony do królestwa zmarłych odbywa się na łące i to kwiaty i zioła, a nawet zboża, którym patronuje Demeter, powinny być wyeksponowane $\mathrm{w}$ tej historii. Jednak Iwaszkiewicz $\mathrm{z}$ osobistych powodów - o czym za moment - wybiera symbol drzewa i jemu każe dać wyraz tajemnicy życia i śmierci. Okazuje się, że intuicja trafnie podpowiada pisarzowi mityczne łło wydarzeń, które dokonały się sub specie aeternitatis oraz sprawiły, iż w królestwie cieni pojawiła się istota żywa. Otóż droga do podziemia wiodła obok figowca, nie występującego w naszym klimacie, i zastąpić go musiała brzoza: „Grecy do dziś czują zabobonny lęk przed spaniem pod figowcem. W wielu miejscach oprócz Eleusis dziki figowiec znaczył wejście do świata podziemnego"7. W związku z tym preferowana przez Iwaszkiewicza figura drzewa wydaje się symbolem o tyle trafniejszym, o ile pełniej wyraża sedno tajemnicy dotyczącej Eleusis:

Misterium niewyczerpanego pojawiania się życia wiąże się z rytmiczną odnową kosmosu. Dlatego właśnie kosmos jest przedstawiony w kształcie ogromnego drzewa: „sposób bycia” kosmosu, a przede wszystkim jego zdolność odradzania się bez końca - znajduje symboliczny wyraz w życiu drzewa8

U Iwaszkiewicza zaś drzewo - brzoza - ściśle wiąże się z kobiecością, te dwie sfery sa wobec siebie komplementarne i tworzą tajemnicę bytu poddanego prawu wiecznie następujących i przez to uzupełniających się wymiarów życia i śmierci. W Brzezinie kobiecość to wszak nie tylko Malwina, lecz także martwa Barbara, ich status istnienia zaś podporządkowany jest prawu wegetacji, prawu chtonicznej przemiany drzewa, które umiera i odnawia się wiecznie.

Dla Iwaszkiewicza połaczenie obu sfer stanowiło coś naturalnego i zjawisko to niejednokrotnie ujawniało się w jego twórczości. Wystarczy przypomnieć piękny wiersz Urania, rozpoczynający się od słów: „Uranio, sosno, siostro” ${ }^{9}$, gdzie oprócz utożsamienia kobiety i drzewa zachodzi znamienne rozszerzenie znaczeń, to utożsamienie uzupełnione zostaje trzecim: metafizycznym - nad wszystkim góruje bowiem inicjalna muza. Przybylski, analizując ten wiersz, wspomina o szczególnej estymie, jaką autor Zmowy mężczyzn darzył drzewa, i powołuje się przy tym na wspomnienie Julii Hartwig:

opowiedziała mi, że kiedy już po śmierci Anny Iwaszkiewicz wraz z Arturem Międzyrzeckim odwiedziła pisarza w Stawisku, po małym spacerze, za powrotem, tuż przed domem objął on drzewo oburącz i przywarł do niego twarzą ${ }^{10}$.

Nie jest to zatem przypadek, że w swym przedwojennym opowiadaniu Iwasz-

7 Kerényi, op. cit., s. 69.

8 M. Eliade, Sacrum - mit - historia. Wybór esejów. Przeł. A. Tat a rkiewicz. Wybór, wstęp M. Czerwiński. Warszawa 1993, s. 150.

9 J. Iwaszkiew icz, Urania. W: Poeci polscy: Jarosław Iwaszkiewicz. Wyd. 2. Warszawa 1983, s. 113.

10 R. Przybyls ki, Mityczna przestrzeń naszych uczuć. Warszawa 2002, s. 94. 
kiewicz za tytułowego bohatera obiera drzewo - brzozę, ta zaś z kolei przeobraża się w kobietę: raz zmysłową, raz martwą.

Tylko z pozoru Stanisław w kontakcie z Malwiną odkrywa pełnię witalizmu, miłość do Malwiny naznaczona jest bowiem śmiercią. Wprawdzie „Eros przekształca świat w harmonijną całość” ${ }^{11}$, jednak jeśli chodzi o życie seksualne Stanisława, nie wszystko zostaje poddane prawu harmonii. Choć fascynuje się on życiem kochając się z Malwiną, wszakże w chwilach uniesień myśli tyleż o niej, co o zmarłej żonie brata, i ten kontrapunkt wprowadza ewidentny dysonans w pozornie uładzony świat Erosa:

Obją ją bez słowa i chudym ramieniem wyczuł jej szerokie plecy, otoczone wypukłymi mięśniami wzgórki kości pacierzowej. Pomyślał o tamtej kobiecie - leżącej w mogile, a potem z czułością, wdzięcznością, rozmarzeniem [...] wtulił swą głowę w jej piersi. [I 363-364]

Doprawdy iście barokowa to harmonia, a miłość Stanisława do Malwiny dziwnym trafem przypominać zaczyna delectatio morosa, co - biorąc pod uwage tezy dotyczące utożsamienia Malwiny z życiem - wydaje się sprzecznością. Jednak sprzecznością nie jest, gdyż Iwaszkiewiczowi zależało raczej na wyeksponowaniu związku między Barbara a kochanką Stasia, tak aby obie współtworzyły obraz już nie witalizmu, lecz kosmosu, który umiera i rodzi się, jak drzewo w swym cyklu rocznym. Nie sposób więc odróżnić, czy miłość z Malwiną na grobie Barbary, pod brzozami, stanowi inicjację w życie czy w śmierć, jedno i drugie to przejawy takiej samej prazasady, o której przypominają mity poświęcone wegetacji i symbolika drzewa kosmicznego. Stąd też w przypadku Stanisława dokonuje się wtajemniczenie w misterium niewyczerpanego rytmu kosmosu i w związku z tym można rzec, że już w owym przedwojennym opowiadaniu Iwaszkiewicza poznaniu bohatera towarzyszy jego muza - Urania. Zreszta podobny indyferentyzm w ocenie tego szczególnego miejsca daje się zaobserwować, jeśli wziąć pod uwagę percepcję Bolesława. Odwiedza on nieustannie ów przydomowy cmentarz, który w pewnym momencie staje się dla niego zmysłową świątynią. Jest to miejsce spotkań Bolesława zarówno ze zmarłą żoną, jak i - po duchowym odrodzeniu - z Malwiną. Ta ostatnia: „Stała obojętna pod drzewem, wsparta o biały pień” (I 398). Zatem wszystko, co najistotniejsze, co owiane tajemnicą uchodzącego i odradzającego się życia dzieje się w tym opowiadaniu w tytułowej brzezinie, która w szczególny sposób każe nam pamiętać, że nie tylko dwaj bracia, lecz także dwie postaci kobiece współtworzą tajemniczy kwadrat uwikłany w odwieczne misterium życia i śmierci.

\section{Malwina}

Nie da się odłączyć witalizmu Malwiny od martwoty świata cieni, w której pogrążyła się Barbara i w którym za życia tkwi Bolesław. Według Przybylskiego Malwina jest „hożą dziewoją młodopolskich poetów [...] podniesioną do rangi odwiecznego mitu” ${ }^{12}$. Jeśli wszakże jest to jedynie odwieczny mit, to owa bohaterka traci na

11 Przybylski, Eros $i$ Tanatos, s. 191.

12 Ibidem, s. 189. 
indywidualności i staje się alegorią. Pytanie tylko, dlaczego tak się dzieje? Otóż wydaje się, że spełnia ona w taki sposób życzenie bohaterów męskich i że potrzebują oni kogoś, kto zrealizuje ich fantazmaty o płodnym życiu, witalności, zmysłowości i obietnicy rozkoszy gwarantowanej przez ustanawiającego harmonię Erosa. Tak naprawdę niewiele można powiedzieć o tym, kim w rzeczywistości jest Malwina i co czuje. Wiemy natomiast bardzo dobrze, czego życzą sobie męscy bohaterowie względem niej. Ciekawe wydaje się to, że w zasadzie $z$ nią nie rozmawiają, jedynie tulą się do niej. Jako ucieleśnienie mitu nie powinna $z$ nimi rozmawiać, lecz przede wszystkim być. I Malwina je st, lecz niejednokrotnie towarzyszy jej milczenie, które tak irytuje Stanisława: „męczyło go ogromnie milczenie tej dziewczyny. Myślał, że czai się poza nim jakaś zasadzka czy tajemnica, której, oczywiście, nie będzie mógł zdobyć" (I 370). Nie zmienia to faktu, że jest ona w Brzezinie bardzo wyraźnie obecna. Mimo że właściwie nie mówi, to cecha ta, jeśli się weźmie pod uwagę chociażby frazeologizm „milczeć jak grób”, kolejny raz wiąże tę żywotną bohaterkę ze zmarłą Barbarą. Zachowanie Malwiny w opowiadaniu równa się jej częściowej nieobecności. Jednak to nie tylko to, lecz także coś na kształt wykluczenia. W zasadzie znajduje się ona bowiem poza porządkiem komunikacji, który przynależy do dyskutujących mężczyzn. Jedynym znakiem obecności jest jej cielesność. Zatem Malwina zazwyczaj oddaje się w milczeniu, to stanowi jej istotę, dlatego według Przybylskiego bohaterka Brzeziny symbolizuje tylko mit kobiecości, i to widzianej z perspektywy pożądającego mężczyzny.

Nawet na tę bierność Stanisław spogląda podejrzliwie, doszukuje się tajemnicy bądź zasadzki. Jednak czy to prawda? Warto tu prześledzić komunikaty Malwiny - są to najczęściej lapidarne odpowiedzi na zadawane przez Stanisława pytania. A status tych krótkich sformułowań mężczyzna każdorazowo deprecjonuje:

Myślał, że od tej chwili Malwina zmieni odpowiedzi na pytania, które jej powtarzał [...]. Że zacznie może ona pytać. Ale nie. Była jak dawniej - pokorna, spokojna, wstydliwa, kłamliwa. W dalszym ciągu mówiła, że nie znała mężczyzn przed Stasiem, że Michał do niej nie chodzi. I na pytanie: czy go kocha, odpowiadała Stasiowi „tak”.

[...]

- No, a Michał - zapytał. - Michała kochasz?

- Tak, też kocham - odpowiedziała cichutko. [I 375]

Na jedno tylko pytanie [Malwina] odpowiadała pełnym i szczerym: tak. [...] Było to pytanie: kochasz mnie? Staś zdawał sobie sprawę, że owo „tak” było równie kłamliwe, jak wszystkie poprzednie „nie”. [I 372]

Powoli pojął, że kobieta, która z nim chodziła po mrocznych ścieżkach lasu, składa się z samego kłamstwa. [I 371]

Zatem w opinii Stanisława język Malwiny to kłamstwo i właściwie nie warto jej o nic pytać, gdyż odpowiedzi nie mają żadnego znaczenia. Bohaterka więc znajduje się poza porządkiem komunikacji, jest wydziedziczona $z$ języka, którym posługują się bracia. Jednak trzeba przy tym sprecyzować, $z$ jakiego systemu mowy korzystaja Stanisław i Bolesław. To typowy język codzienny, bohaterowie mówią, a w zasadzie dialogują, opierając swą argumentację na prawach dwuwartościowej logiki. Właśnie owa logika każe traktować wypowiedzi Malwiny jako kłamstwo, dlatego Staś praktycznie utożsamia ją z kłamstwem. Należałoby jeszcze zaznaczyć, 
iż deklaracja, że Staś jest jej jedynym ukochanym, i zarazem uwaga, że kocha także Michała, nie musi być kłamstwem, jeśli odrzucić prymat logiki dwuwartościowej, w której afirmacja jednej opcji implikuje negację wszystkich pozostałych. W rzeczywistości w zdaniu Malwiny na szwank została narażona ontologiczna zasada niesprzeczności: ,jeśli kocham Stasia, to nie mogę kochać nikogo innego”.

Jeśli zaś prawo tej logiki nie dotyczy sposobu myślenia bohaterki, to trzeba zapytać: w jakich kategoriach postrzega ona świat? Można przyjąć, że jest to archaiczny (niezgodny z zasadami arystotelejskiego organonu) sposób myślenia i komunikowania się, swoisty język pierwotny, gdzie inaczej interpretowane sa kategorie prawdy i kłamstwa. Owe struktury poprzedzające logikę rządzą się odmiennymi prawami i nie przystaja do wzorca wypracowanego przez bohaterów męskich. O ile tym ostatnim w ich języku przyświeca logos, o tyle Malwina posługuje się raczej komunikatem przynależnym sferze mythos, gdzie prawa logiki dwuwartościowej nie muszą obowiązywać. Tak za Jeanem-Pierrem Vernantem relacjonuje tę dychotomię Krzysztof Piątkowski:

Wraz z rozwojem myśli filozoficznej, refleksji historycznej, gdzieś od początków V w. p.n.e. sens tego drugiego słowa [tj. logos] zbliżył się do pojęcia „inteligencji”, „rozumu”, spychając pojęcie „mythos” w pogardliwe odniesienia do pozbawionego sensu czy podstaw, nieuzasadnionego, nieudokumentowanego, próżnego gadania ${ }^{13}$.

Zatem język Malwiny nie jest kłamstwem, lecz stanowi opowieść zamierzchła, archaiczną, mityczną, więc taką, w której logos i jego prawa jeszcze nie istnieją. Racjonalny, trzeźwy Stanisław nie znajduje na tę formę wypowiedzi innego określenia niż kłamstwo, jednak jest to fałsz tylko z pozoru. Mythos, czyli opowieść nie poddająca się prawu dialogicznej logiki dwuwartościowej, ma swe atrybuty, którymi nie dysponuje codzienna komunikacja. Otóż wydaje się, że jego największą zaletę stanowi udział w artystycznym sposobie widzenia świata. Językiem Malwiny jest mythos, a mową także melos, czyli śpiew. Żywioł muzyczny jest czymś, co wynosi jej komunikaty ponad pospolitą logikę. Pamiętamy wszak, że bohaterka w obliczu agonii Stanisława rozpoczyna eksklamację kurpiowskiej pieśni żałobnej. Spełnia się przy tym marzenie wyrażane przez Friedricha Nietzschego w Narodzinach tragedii:

Z tych zrozumiałych w sobie i głębszemu badaniu dostępnych faktów wysnuwam zdolność muzyki do rodzenia mitu, to jest najznaczniejszego przykładu i właśnie mitu tragicznego: mitu, który o dionizyjskim poznaniu mówi w przenośniach ${ }^{14}$.

Mowa Malwiny jest kłamstwem tylko z apollińskiej, logicznej perspektywy. $\mathrm{W}$ istocie dotyka ona w języku tego, co najbardziej zamierzchłe i archaiczne - opowieści, w której możliwe wydają się sprzeczności, i zarazem potrafi nazwać to, na co w potocznej konwersacji nie ma słów, to, co najbardziej przejmujące i wzniosłe. Umie opisać śmierć ukochanego, sięgając po melos i eksklamując swój lament,

K. Piąt kowski, Mit - historia-pamięć. Kulturowe konteksty antropologii/etnologii. Łódź 2011, s. 76 .

14 F. Ni ietz s c he, Narodziny tragedii, czyli hellenizmi pesymizm. Przeł. L. St aff. Posł. T. Ma ci os. Kraków 2003, s. 74. 
wznosi się ponad porządek logicznego dyskursu. Jest tym samym artystką, choć ściślej należałoby ją raczej nazwać artystką mediumiczną: to przez nią wyraża się poruszająca pieśn kurpiowska, chwytający za serce lament, nie do opisania w zwyczajnym, komunikatywnym języku. Jeśli zaś Malwina jest także artystką, to wydaje się, iż traktowanie Stanisława wyłącznie jako postaci percypującej rzeczywistość przez pryzmat wzruszeń estetycznych pomija przejmująca wrażliwość Malwiny. W studium Przybylskiego mówi się, że „Jak Wiktor Ruben, Staś ma również naturę artystyczna.. Jest muzykalny"15. Należałoby jednak dodać, iż mediumiczną, dionizyjską artystką okazuje się też Malwina. O ile Stasia cechuje wrażliwość apollińska i nie jest on w stanie zmierzyć się z tragicznym losem gruźlika, to dionizyjska głębia śpiewu kochanki dotyka sedna nieodwołalnego wyroku, jaki zapadł w związku z losem chorego. Zatem melos Malwiny czyni z niej istotę, która nie tyle kłamie, jak chca tego mężczyźni, ile nazywa najwznioślejszą prawdę o losie człowieka, nie dającą się wypowiedzieć poprzez dyskursywny język.

\section{Kwadrat}

Najczęściej bohaterów Brzeziny ujmuje się w przeciwstawne sobie pary. Są mężczyźni i kobiety, jest martwe - dosłownie i metaforycznie - małżeństwo Bolesława i Barbary oraz pełen witalizmu duet Stanisława i Malwiny. Wydaje się jednak, że cała czwórka głównych bohaterów współtworzy zadziwiająca wspólnotę połączoną najróżniejszymi, paradoksalnymi więziami. Wspominałem już o zaskakujących schadzkach Stanisława i Malwiny na grobie Barbary i osobliwych fantazmatach gruźlika w chwilach uniesien, kiedy to wyobrażał sobie martwą żonę brata jako obiekt pożądania. Stanisława łączy wiele $z$ Malwina, ale właściwie łączy go sporo także z Barbara. Nie tylko poprzez fantazmaty. Ostatecznie zostaje on pochowany u boku żony brata, tak jakby to nie Bolesław, ale on był pełnoprawnym mężem matki Oli.

Bolesław zaś w końcówce opowiadania tuli się do Malwiny, jak zazwyczaj zwykł to czynić jego chory brat. Iwaszkiewicz przedstawia Bolesława jako pogrą̇̇onego w melancholii po śmierci żony, lecz w ostatnich scenach widzimy, że tryska zadowoleniem i wigorem. W świecie Brzeziny zatem nie ma jednoznacznego podziału na sfere życia i witalności oraz przeciwstawiona jej martwotę. W królestwie cieni zdarza się bowiem uniesienie erotyczne, a pełnia życia w każdej chwili może przeobrazić się w odrętwienie i nicość. To pomieszanie znaczeń wydaje się ostatecznym potwierdzeniem tezy, jakoby Brzezina Iwaszkiewicza próbowała odwzorować aurę misteriów eleuzyńskich $z$ ich niejednoznacznością, związaną $z$ faktem zespolenia swiata żywych i umarłych. Persefona bowiem wprowadziła wiele zamętu w ów wyraźnie oddzielony świat:

Oba królestwa zostały teraz zrównane i jedno otwierało się w stronę drugiego. Hades narzucił ziemi nieobecność, narzucił fakt, że każda obecność została okryta znacznie obszerniejszym płaszczem nieobecności. Persefona sprawiła, że wśród zmarłych pojawiła się krew [...], krew istoty, która w dalszym ciagu pozostaje w pełni żywa, chociaż znalazła się w pałacu śmierci ${ }^{16}$. 
Ten indyferentyzm w pełni występuje w Brzezinie, a niedoceniane i pozostające w cieniu żeńskie postaci łączy więź bliska matce i córce z eleuzyńskiego mitu. Dlatego warto także i o nich wspomnieć i nie egzaltować się powierzchownymi doznaniami Stanisława i Bolesława. W historii kobiet do głosu dochodzi bowiem cała tajemnica dionizyjskiej prawdy o człowieku, prawdy bronionej tak przez Nietzschego. Jest to prawda o tragicznym losie człowieka, który jednak nie pogrąża się w rozpaczy, lecz stara się tym głębiej doświadczyć, czym jest życie.

\section{Abstract \\ MARCIN CAŁBECKI University of Gdańsk}

THE KURPIE ELEUSIS ON HEROINES OF JAROSŁAW IWASZKIEWICZ'S "BRZEZINA" ("THE BIRCH WOOD")

The article is an attempt at interpreting the function played in Jarosław Iwaszkiewicz's story by two female characters. In most important research in Brzezina (The Birch Wood) literary historians exclusively indicate the leading role of two brothers. Malwina and Barbara, two background figures, are, however, rightful heroines of the drama taking place in Boleslaw's ranger's station. Only when analysing such a complex relation can we deeper understand the prose and comprehend the reasons Iwaszkiewicz gave such a mysterious title to his piece. 